\title{
Kids Playing At School: Ethnography about Race, Gender, Class and Region
}

\author{
PEREIRA, Simone dos Santos ${ }^{1}$ \\ NASCIMENTO, Silvana de Souza ${ }^{2}$
}

\begin{abstract}
The school curriculum is the most important feature to understand what types of values are desired to a community. No matter in what level it is being proposed, from the country's government policies to the closed door classroom, specific curriculum strategies and contents are planned and executed in order to teach the students one's view. The main aim of this paper is to unveil how the social markers of difference such as race, gender, class, profession, etc are interconnected and are experienced by children at school. This anthropological study has been carried out since 2018 in a kindergarten school on the outskirts of the city of São Paulo, in Brazil. It is based on the ethnographic method with a participant observation technique. This institution has been chosen because its curriculum proposal is very singular considering others schools in the country. It focuses on the diversity, which includes concerns about race, ethnicity, gender, social class, religion, among others social markers. The selected teachers have been working, since 2014, to clarify how power relations were constructed in Brazil in order to classify people, hierarchizing relationships. At the same time, they conduct teaching how to identify, understand and face inequalities in the interest of overcoming them. This paper discusses that kids are involved by multiple discourses and, in a way, they understand how they face stereotypes in society and the political issues proposed by the school pedagogical practice. Primarily observations indicate that confrontations take place on daily basis when conservative children, families and educators face the new progressive ideas proposed by the school curriculum, they are normally related to stagnated hierarchies (and consequently inequalities) on gender, race, ethnicity, profession, etc.
\end{abstract}

Key-words: Early childhood education, Race, Gender, Ethnography

\section{Introduction}

Through centuries persons were kidnapped from the African continent to be slaved in the America colonies, as well as the native people, they were oppressed. It is well-known that the colonization processes from the 15th century onwards exploited and destroyed cultures, languages, regions, etc. Products of an official ethnocentric, androcentric, Western/ Nothern-centric discourse the ethnic groups that constituted the formation of the Brazilian population were, for a long time, reported as inferior, savage, uncultured, subordinated, among other pejorative adjectives (re)affirming and highlighting the processes of exclusion in society and history.

According to statistics by the Brazilian Institute of Geography and Statistics (IBGE), from the last two decades, people evaded from school, socially vulnerable, deprived of liberty among other excluded groups usually point out inequalities that articulate race/ ethnicity, class, gender, age and so on. "Each of these classification categories is related to a specific social position, has a history and attributes certain common characteristics to the individuals grouped in it" explains Zamboni (2014, p. 13-14, our translation). These systems are social markers of difference. In Brazil, they have been historically regulating certain patterns of identities and behaviors, producing and reproducing contrasts, positioning the bodies of descendants of African and indigenous people at the lowest classification in social hierarchies.

The myth of racial democracy (Fernandes, 1965; Freyre, 1992) suggests that these people, marked by color/ race/ ethnicity, are embedded in an unequal process in which different types of violence are naturalized. This idea was promoted at schools in the country during generations.

\footnotetext{
${ }^{1} \mathrm{PhD}$ researcher at the Social Anthropology Post-Graduation Program at School of Philosophy, Literature and Human Sciences (FFLCH) at University of São Paulo (USP). Master in Education from School of Education at USP. Orcid: https://orcid.org/0000-0003-3177-2575. E-mail: simone.pereira@ alumni.usp.br.

${ }^{2}$ Doctor in Anthropology (USP).Professor of Anthropology at FFLCH. Coordinator of the Laboratory of the Urban Anthropology Centre and of the Collective Cóccix - Studies of the Body and the City at USP. Researcher at Humanities, Rights and Others Legitimacies (Diversitas) at the same university.Orcid: https://orcid.org/0000-0001-5661-4915. E-mail: silnasc@usp.br.

${ }^{3}$ Cada uma dessas categorias de classificação está associada a uma determinada posição social, possui uma história e atribui certas características em comum aos indivíduos nela agrupados.
} 
Only at the end of the $20^{\text {th }}$ century, in 1997, the Ministry of Education publishes a referential document, the National Curriculum Parameters ${ }^{4}$, which rereads this trajectory. According to the text, official actions propagated

an idea of a Brazil without differences, originally formed by the three races - the Indian, the white and the black - that dissolved, giving birth to the Brazilian. Such social myth was also disseminated at schools and in textbooks, sometimes seeking to neutralize cultural differences, sometimes subordinating one culture to another. A concept of a uniform culture was disseminated, depreciating the diverse contributions that drew up and draw up the national identity ${ }^{5}$. (PCN, 1997 , p. 25 , our translation)

'In the process of fabricating History, from the winners' point of view, the idea of a unique national identity was reaffirmed by the concealment of productions of differences and, consequently, of inequalities" ${ }^{\prime 6}$, interpret Pereira and Nascimento (2020, p. 491).

Only in the beginning of the 21 st century other educational laws (e.g. 10.639/2003; 11.645/2008) reinforced the need of exploring the history and cultural aspects of these peoples in Basic Education. Even though, unequal power relations position and disqualify certain bodies inside and outside school. The fabrication of a single story (Adichie, 2009) elects, values and legitimates standards of what is true and good from the white and heteronormative supremacy reinforcing naturalizations of colonizing and dualistic relations: between the white and the black, the good and the evil, the right and the wrong, the beautiful and the grotesque, the included and the excluded (Pereira, Nascimento, 2020). These discourses produce and reproduce discrimination with and among black children at school (Cavalleiro, 1999; Oliveira and Abramowicz, 2010; Nunes, 2013, among others). It is urgent to end this.

According to the Brazilian educator Paulo Freire, education is a path to social changes. For him, education itself does not transform the world, but it does change people and people are able to change the world. Considering the need for these transformations, this anthropological research is being conducted in a Municipal School of Early Childhood Education $^{7}(E M E I)^{8}$ located in a peripheral region of the city of São Paulo, Brazil. This institution carries out a political and pedagogical project focusing on "ethnic-racial relations, working with indigenous themes and African matrices, diversity and racial equality"9 (EMEI, 2018, p. 25, our translation).

The objective in the Ph.D. research is to understand how the social markers of difference are interconnected and are experienced in the relationships inside the school community. The ethnographic research, based on participant observation, reveal tensions among the various discourses from institutions (family, church, state, and so on) that affect the school people, as well as how the pedagogical work is planned and performed in order to face racial inequalities, reframing and contributing to a more equitable society, from the empowerment of black and non-black children, moreover the adults involved.

The curriculum proposal, with the objective of promoting ways to value human diversity and to reduce inequalities, prioritizing, in the school routine, reflections on issues of ethnicity/ race/ color and cultural diversity. The Special Plan of Action named "(Re)discovering childhoods and transforming practices: Ethnic-Racial education, bringing different cultures together, respecting diversity and promoting equality in early education" has been structured, since 2014, to enable debates about ethnicity, diversity, identity, among other topics. These issues, according to the document, are necessary to build a democratic, egalitarian and anti-racist society.

The purpose of this paper is to show how children experience race, gender, class, among other social markers outside and inside the school. For that we will narrate two situations observed at playing time. We will argue that the kids are

\footnotetext{
${ }^{4}$ Such document describes references for Elementary School's subjects as a mean to guarantee a common curricular proposal. They were offered to teachers to guide education in the country.

${ }^{5}$ Disseminou-se, por um lado, uma ideia de um Brasil sem diferenças, formado originalmente pelas três raças — o índio, o branco e o negro - que se dissolveram, dando origem ao brasileiro. Tal mito social também foi veiculado na escola e nos livros didáticos, procurando àsvezes neutralizar as diferenças culturais, às vezes subordinar uma cultura à outra. Divulgou-se, então, uma concepção de cultura uniforme, depreciando as diversas contribuições que compuseram e compõem a identidade nacional.

${ }^{6}$ No processo de fabricação da história, a partir do ponto de vista dos vencedores, a ideia de uma identidade nacional única se reafirmava pelo ocultamento de produções de diferenças e, consequentemente, de desigualdades.

${ }^{7}$ We would like to thank everyone in the school community as well as Esther G. Borges and Victor Augusto C. Pacheco for reviewing and commenting on the text in English.

${ }^{8}$ This school was chosen because a school project aiming afro and indigenous people is rare in Brazil.

${ }^{9}$ Relações étnico-raciais, trabalhando com a temática indígena e com as matrizes africanas, diversidade e igualdade racial
} 
involved by multiple discourses and, in a way, they understand the political issues proposed by the school pedagogical practice and how they face stereotypes in society. The topics of analyzes are under construction and open to dialogues.

\section{Children playing at school}

In this paper, among all the observed interactions, we choose to present two situations that intersect gender, race, class among others social markers of difference. They were also selected because one of the researchers was directly involved.

\section{Black woman's hair}

One morning I arrived at the classroom at a "free play time". As usual, I did not interfere in the situation, I sat away from the children who were playing with each other at their chair, in groups of four, sitting around the tables. I started writing in my diary field notes such as how many children were there that day. Two black girls approached me and asked if they could play with my hair as if we were in a beauty parlor. As it was untangled and loose I said yes. They took some toys and started manipulating it.

Kalifa $^{10}$ said: "Your hair is cool, it is beautiful. Can I make a braid?". I responded yes. She took the toy dryer and began to dry it. She pretended to apply some leave-in conditioner and started braiding it. Meanwhile, she explained: "I like braids, my mother braids my hair. Your hair will look just as beautiful". On my right side was Adia (A). When she started playing with the dryer she said:

A: We need to dry it.

I nodded.

A: After I dry I will use the hair straightener, then your hair is going to be smooth and very beautiful!

I asked (S): Why do you need to use the hair straightener to make my hair look good?

A: It looks better this way.

S: Ah, but I don't want the hair straightener. I love my curly hair. I don't like it straight.

She was in silence for a while and said: Ah, like "Tayó", but we don't have anything to put in your hair.

I touched her hair and said: "Just like your hair. Your hair is so beautiful. Who make this amazing hairstyle on it?".She smiled, left the straightener on the table and replied: "my sister".

She spent some minutes touching my hair and said: ok, let's put some leave-in conditioner and that is it!

Every day after that, she came to talk to me and I mentioned how beautiful her hair was with that particular hairstyle. She always replied proudly that her sister had done it. She used to say she was going to introduce me her sister. A few months later, at a Cultural Festival at school I had the opportunity to meet her. During our conversation, her sister, who was about sixteen years old, pointed out that instead of complaining about brushing her hair, Adia started asking "please make a very beautiful hairstyle, the new teacher like my hair and the hairstyles very much".

These interactions signal latent questions about black women's hair. Kalifa liked the treatment she received on her own hair and included it in her make-believe playing. The dialogue shows how she handles the afro hair positively. Her actions can be understood as recollection of experienced moments with her mother, which embraces possibly care, affection, praises, conversations, etc.

Although Adia had a beautiful hairstyle, she preferred to play with the hair straightener, explaining that the transformation would make the hair beautiful. In this statement there was an understanding that curly hair could be beautiful only if it was straight. Throughout the playing and the conversation Adia remembered other moments at school and possibly resignified the tremendous possibilities of hairstyles that bring beauty to a curly hair.

The school carries a continuous work of acceptance and empowerment of black hair. Among the actions there are workshops on afro hairstyles, turbans, braids, among others.

\footnotetext{
${ }^{10}$ All the names have been changed to preserve the identity of the people involved in this research. The names come from theAfricancontinent: Kalifameans "shining" and comes fromSuaili, Kenya. Adia isequalto "a gift" (Hausa, Nigeria). Tebogo (Tswana, Botswana) is equivalent to "we are grateful". Ghedimeans "traveler" (Somali, Somalia) andYooku (Fanti, Ghana) signifies "born on a Wednesday". S stands for Simone, oneoftheresearchers. 

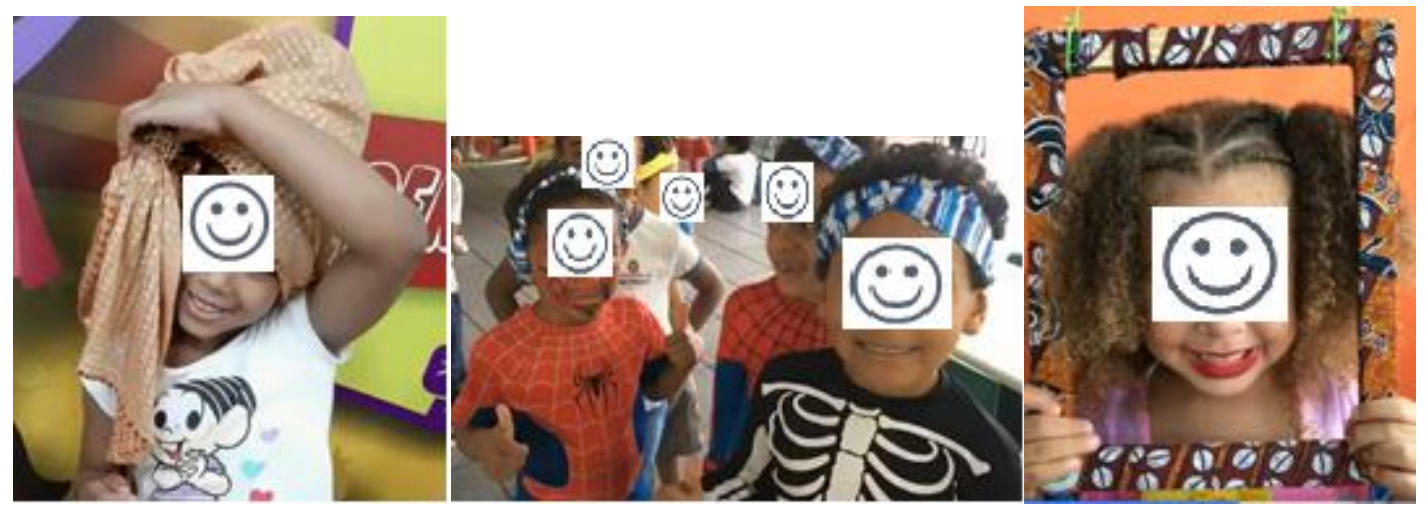

Source: School page at Facebook ${ }^{11}$.

It is common to read children's book in which the protagonist is an African descent and has a positive relationship with her/ his hair. Among them is the book mentioned by AdiaThe world in Tayó 's black power, written by Kiusam de Oliveira. The book tells a story of a child who carries joy, ancestry and empowerment within her hair.

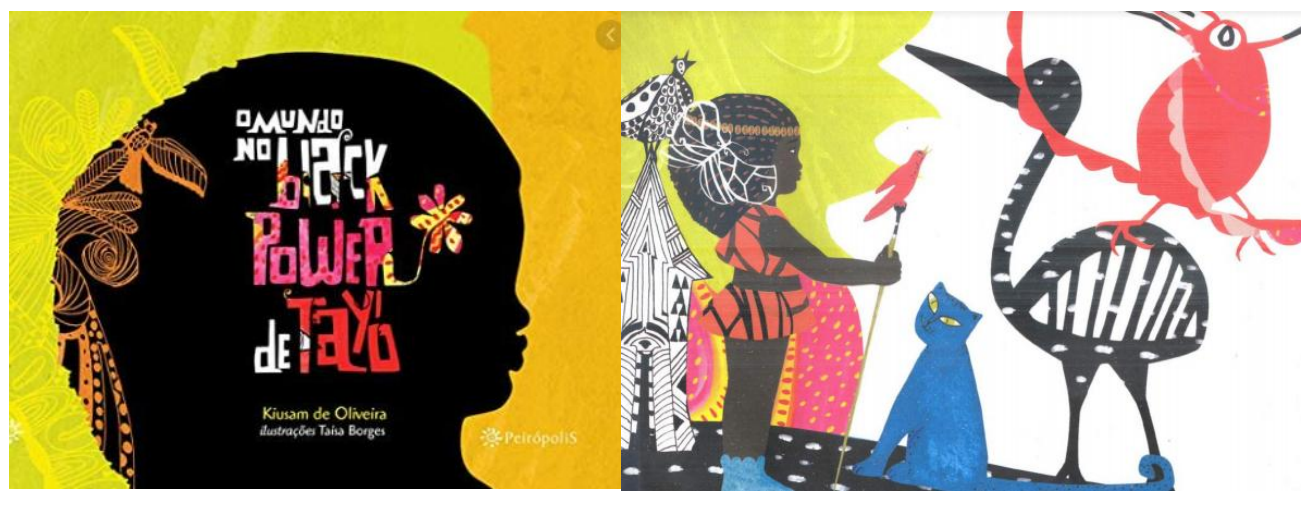

Source: Images from the book.

It is possible to consider, besides the social markers race and gender, that such interactions involves class and region. Social class is implied in the knowledge of hair treatments in Beauty parlors. The kids specifically named the game that, which shows how precious a moment at that exact place may be. The toys themselves also demonstrate that they are familiar to the kids. We also consider that it could occur mainly in an urban environment in which the Beauty Salon (frequented or not) is present in the children's daily lives inside and outside school ${ }^{12}$. Easy access to toys such as dryers, straighteners, mirrors, etc can also be related to high turnover of consumption of these objects in large cities ${ }^{13}$.

\section{The "Police and "enquadro" game}

When I was watching the kids in the synthetic grass park playing "police and thief" the first thing I realized was that children who were interpreting police officers touched the thieves aggressively. The dialogue (which was actually a monologue because only the police had the right to speak) was normally given like this: "Stop, tramp", "Be quiet, I will check you out", "Shut up, 'pretofolgado"", etc. The touches on the thief's body were hostile: touching/ pushing against the wall, throwing him on the floor, searching, etc. The game was summed up to this, catching the thief and searching him hostilely and violently (morally and physically). When the game was done, the boys who played the thieves said: "now it's my turn", and it meant "now it's my turn to be the policeman".

\footnotetext{
${ }^{11}$ Available at: https://web.facebook.com/emeicarolinamaria.

12 In a process of attentive listening to the children in 2018, the kids' playroom was renovated and five spaces were included. Everything was elected and voted by them, including the Beauty Salon. The others were: a kitchen, a doctor/ dentist's office, a mechanic shop, a superheroes and super heroines shop.

${ }^{13} \mathrm{We}$ are talking about specificities in large and small cities in Brazil and we understand that there may be variations from country to country.
} 
After some time observing the children play, I talked to them. When I asked the name of the game, they answered "police e enquadro"". I questioned how one could play it and Tebogo told me: "well, the policeman runs after the kid, stop him and start to shout". I insisted: "isn't it called 'police and thief". Guedi spoke: "it is 'police and enquadro' because the police stops everyone, all people on the street, and they are not thieves". I asked if would happen to everybody on the street: boys, girls, children, adults, elderly... Tebogo replies: "no, just boys and men" (Field diary, March, 2019).

On another day of observation, it was evident that the police were always the same boy, a white boy. When I inquired him if they switched roles, he replied:

Yooku(Y): No, with these friends only I am the police. They all have to stay on the floor.

S: Why?

Y: The police don't stop me, they stop them.

S: Why? Do you live in different places?

Y: No, we live on the same street.

S: So, what is the difference?

He chuckles, makes a gun gesture with both hands close to his chest and says: "ah, we are different", and runs away. (Field diary, May 2019)

It is possible to observe with these situations some understandings that children place in relation to race, gender and profession. In the first report, the choices of both characters are indistinct, everyone may have the possibility to choose the two roles occupying both social positions. In the second case, it is likely to point out that the white boy, in addition to playing, understands some social markers and discriminates social positions by simultaneously playing only one role (the police) and refusing to occupy the other (a regular citizen). It can be inferred that all children perceive gender and age markers, since only men, in the place where they live, go through this situation. When including the color classification, it was clear that the white boy refused to take the position of "thief" or "enquadrado", because in his understanding such a position could not be occupied by people with his characteristic (or color).

The white child generated a situation of unequal power relation with an exclusionary character and dominantdominated nature. There were, at the same time, silences from the biracial and black boys who underwent to be "enquadrado" without disputing, at that moment, the position of the (white) policeman. What does this mean in the subjective and the concrete, in the individual and the collective, in the present and the future of these poor, urban black boys?

The questions of social class and region are perhaps imperceptible to the children because they live in local communities. No localization context was observed to indicate this would happen in a given location, however we understand that this is a constant situation in peripheries and communities in large cities. The school is located between two communities in the city of São Paulo, however these situations could have happened in any slum such as Rocinha in Rio de Janeiro, Sol Nascente in Brasilia, among others. Perhaps the boys do not fully understand the differences inside the concepts of social class and region, perhaps they have not been to places far from their neighborhood. However, somehow they know something is different (or wrong) when they say they are not playing "police and thief" because "the police stops everyone, all people on the street, and they are not thieves".

The profession marker was evident, indicating power, authority and prestige relations of those who take the place of the police. This occupation, for these children, carries with it great psychological, physical and instrumental strength as well as it implies other subjective relations. The game of social positions, by binary oppositions of Western society, results in the prevalence of only one position in this game for the non-black boy.

At the same time, this occupation invokes concrete possibilities of profession for black and poor children. Nunes (2017) reports a teacher insisting for a black child to do an activity justifying that he "needs to study to be strong and hardworking". He, very quietly, replies: "but I don't want to be that". Nunes analyzes it is important to understand the child's answer "as a response of black boys who do not want to conform to a model of society in which they are seen as replacing a racial "stock" to maintain privileges of a racial group at the expense of others" ${ }^{15}$ (2017, p. 283, emphasis in

\footnotetext{
${ }^{14} \mathrm{~A}$ literal translationto 'enquadro' wouldbe 'framed'. It is used as slang when "someone is stopped and searched by an authority for 'no reason'".

${ }^{15}$ como uma resposta dos meninos negros que não querem se conformar a um modelo de sociedade em que eles sejam vistos como reposição de um "estoque" racial para a manutenção dos privilégios de um grupo racial em detrimento de outros" (p. 283). 
original, our translation). This child shows knowledge of the work of the black man, perhaps both from this direct contact and his (non) representativeness in the media.

Professions are also marked by color and black people in Brazil usually work in jobs which do not require high qualifications. What are the jobs of black men in the social life of the EMEI's children? From the concrete experience of these children, the occupation of police, as positive and valued, gains prominence since another possibility for their future is situated in the role of the "enquadrado". It is a real condition, in the communities where they live, to see young people and black adults (including their relatives) being taken by the police to reformatories and prisons. Thus, imagining being a policeman in this condition also involves not being in the opposite position.

A different approach is reported in a research in Rio Grande do Norte with boys and girls aged 10 to 13 . It points out another understanding of the police and the people in a very poor neighborhood:

While the teacher was copying the task on the board, a student said "that night there were so many bullets close to home, there was a shootout, it was each crash". Galega replied: I could hear them from home too", I asked if they knew what had happened and a student replied "it was the police, the bandits don't do this here, they respect us in the community, if one day we're passing and they're smoking [usually marihuana] they stopped for us to pass, who shoots is the police"16 (MANGUINHO, 2019, p. 96, our translation)

The games and the talks may reveal how children recognize social and institutional organizations in the world. The absence of problematization from the school in such situations may fix the silenced black children in the position of "enquadrado". These same individuals possibly "in adult life will accept prejudices and social injustices, also passively, without asking their meaning and reason for being" $"$ (PARO, 2011, p. 132, our translation).

It is normal to observe the teachers talking to the children about professions, as aforesaid in the playroom, for example. They also have others initiatives where they include profession on the speeches. Every year, in August, each group at school selects a prominent (dead or alive) Afro-Brazilian person. During the whole month, they study about that person, learning and discussing about their life, profession, conquers, etc. Duringthe year, some people from different countries of the African continent visit the school. The teachers organize the groups to interview them. The profession is a key question to know about the person and to understand what it embraces in the particular society. Others moments in everyday life at school (when they are playing, reading a book, etc) the topic is also discussed.

When talking to the pedagogical coordinator about the situations, she explained that eventually they play in this way and she would arrange a meeting with other teachers who made the same reports to seek possible ways, in addition to the circles of conversations already held, to deal specifically with this issue.

\section{Closing remarks}

We have made a brief journey with children daily life examples of conflicting situations which intersect race, gender, class, profession and region. These interactions reveal different discourses about the ways of existing in society. The research shows that the EMEI has carried out an intense, extensive and collective work in order to value differences and face inequalities, problematizing and enabling people in the school community to reinterpret various social issues.

We emphasize the importance that (others) schools listen carefully to children and enable multiple engaged and positive relationships with and about bodies in order to destigmatize deep-seated prejudices so that inequalities can be overcome.

\footnotetext{
16 "enquanto a professora copiava a tarefa no quadro, um aluno falou "essa noite foi tanta bala lá perto de casa, teve tiroteio, era cada pipoco!", Galega respondeu "deu pra escutar lá de casa também", perguntei se eles sabiam o que tinha acontecido e um aluno respondeu "foi a polícia, os bandidos não fazem isso aqui não, eles respeitam nós da comunidade, se uma dia a gente tiver passando e eles tiverem fumando, eles param pra nós passar, quem mete bala é a polícia". (2019, p. 96)

17 "na vida adulta aceitará preconceitos e injustiças sociais, também passivamente, sem perguntar seu significado e razão de ser" (PARO, 2011, p. 132).
} 


\section{References}

ADICHIE, Chimamanda. The dangerofthe single story. TED Global. Digital. Available at: https://www.youtube.com/watch?v=D9Ihs241zeg. Access on: Sep 1 $1^{\text {st }}, 2020$.

BRASIL. Secretaria de Educação Fundamental. Parâmetros Curriculares Nacionais: Pluralidade cultural, orientação sexual/ Secretaria de Educação Fundamental. Brasília: MEC/SEF, 1997.

Lei $n^{\circ} 10.639$. Estabelece as diretrizes e bases da educação nacional, para incluir no currículo oficial da Rede de Ensino a obrigatoriedade da temática "História e Cultura Afro-Brasileira" Brasília. DF, 2003.

. Lei $n^{\circ}$ 11.645. Estabelece as diretrizes e bases da educação nacional, para incluir no currículo oficial da rede de ensino a obrigatoriedade da temática "História e Cultura Afro--Brasileira e Indígena". Brasília. DF, 2008.

CAVALLEIRO, Eliane dos S. O processo de socializaçãonaeducação infantil: a construção do silêncio e da submissão. Rev. Bras. Cresc.Des. Hum. S. Paulo, 12(2), 1999. P. 39-49. Availableat: http://www.revistas.usp.br/jhgd/article/view/39447. Access on: Sep 1 $1^{\text {st }}, 2020$.

EMEI CAROLINA MARIA DE JESUS.ProjetoPolíticoPedagógico. São Paulo: EMEI Carolina Maria de Jesus, 2018.

FERNANDES, Florestan. Aintegração do negro nasociedade de classes. Vol. 1 - O legado da raçabranca. São Paulo: Dominus/EditoraUniversidade de São Paulo, 1965.

FREYRE, Gilberto. Casa Grande \&Senzala: formação da famíliabrasileira sob o regime da economiapatriarcal, Rio de Janeiro, Schimidt. 1933.

MANGUINHO Julyana V. de F. Práticas feministas em contextos educacionais. Tese (doutorado) - Universidade Federal do Rio Grande do Norte. Centro de Ciências, Humanas, Letras e Artes. Pós-graduação em Antropologia Social. Natal, RN, 2018.

NUNES, Mighian D. F. Mandingas da infância: as culturas das criançaspequenasnaescola municipal Malê Debalê, em Salvador (BA). 2017. Tese (DoutoradoemEducação) - Faculdade de Educação, Universidade de São Paulo, São Paulo, 2017. doi:10.11606/T.48.2018.tde-05122017-130043. Access on: Sep $1^{\text {st }}, 2020$.

OLIVEIRA, Fabiana de; ABRAMOWICZ, Anete.Infância, raça e "paparicação".EducaçãoemRevista.vol.26 no.2 Belo Horizonte Aug. 2010. p. 209-226. Available at: https://www.scielo.br/scielo.php?pid=S010246982010000200010\&script=sci_abstract\&tlng=pt. Access on: Sep $1^{\text {st }}, 2020$.

OLIVEIRA, Kiusam. O mundo no black power de Tayó. São Paulo: Editora Peirópolis, 2013.

PARO, Vitor H. Crítica da estrutura da escola. São Paulo: Cortez, 2011. 248 p.

PEREIRA, Simone, NASCIMENTO, Iracema. Literaturainfantil com personagensnegras: narrativasdescolonizadorasparanovasconstruções identitários. RevistaEspaçoPedagógico. Passo Fundo, Vol.27, no. 2, maio-ago./ 2020, p. 482-496. Available at :http://seer.upf.br/index.php/rep/article/view/11440/114115319. Access on:Sep 1 ${ }^{\text {st }}, 2020$.

ZAMBONI, Márcio. Márcio. Marcadores Sociais da diferença. Sociologia: grandestemas do conhecimento (Especial Desigualdades), São Paulo, v. 1, p. 14 - 18, 01 ago. 2014. Available at: https://assets-dossies-ipgv2.nyc3.digitaloceanspaces.com/sites/2/2018/02/ZAMBONI_MarcadoresSociais.pdf. Access on: Sep 1 ${ }^{\text {st }}, 2020$. 